\title{
The history of Andøya Rocket Range
}

\author{
Eivind V. Thrane ${ }^{1, a, b, *}$ \\ ${ }^{1}$ University of Oslo, Oslo, Norway \\ aformerly at: Norwegian Defence Research Est., Kjeller, Norway \\ ${ }^{\mathrm{b}}$ formerly at: Andøya Rocket Range, Andøya, Norway \\ * retired
}

Correspondence: Eivind V. Thrane (e-vi-t@online.no)

Received: 15 September 2018 - Accepted: 22 November 2018 - Published: 7 December 2018

\begin{abstract}
Just 5 years after Sputnik, on 18 August 1962, Norway launched the first sounding rocket from Andøya in northern Norway. The establishment of Andøya Rocket Range (ARR), in the Arctic and right in the middle of the night-time auroral zone, gave the scientists unique opportunities for studies of the complex processes in the auroral ionosphere and upper atmosphere. In close cooperation with the users, ARR gradually developed its technical and scientific infrastructure and is now one of the world's leading observatories in this field. ARR has also established a launch site at Svalbard, and sounding rockets from both ranges can reach far into the Arctic to study the cusp region and the daytime aurora. The ground-based instruments comprise sophisticated radars and lidars as well as passive instruments. ARR also plays an active role in space education. In 2014 Andøya Rocket Range changed its name to Andøya Space Center (ASC; https://www.andoyaspace.no, last access: 23 November 2018). This change reflects the fact that the activities now comprise much more than sounding rocket launches. ASC is an important company both nationally and in the local community of Andenes. ASC now has a staff of 95 and an annual turnover of NOK 150 million.
\end{abstract}

\section{Background}

On 18 August 1962 the first sounding rocket was launched from Andøya Rocket Range (ARR), just 5 years after the launch of Sputnik 1 initiated the space age. Several factors contributed to the rapid establishment of a sounding rocket launch facility in northern Norway.

Firstly, Norway has a long tradition in observations of the aurora borealis, and indeed professor Kristian Birkeland is regarded as one of the founders of modern space physics. At the University of Oslo, auroral research started with the pioneering work of Birkeland, Carl Størmer and Lars Vegard. In 1928 the Northern Lights Observatory in Troms $\varnothing$ was established with Leiv Harang as its first director. Norway's geographical position is ideal for studies of the aurora borealis and the Arctic ionosphere. Thus, the zone of maximum occurrence of the night-time aurora is located over northern Norway, and during daytime the auroral zone is located above Svalbard, an archipelago under Norwegian jurisdiction (Feldstein, 1964). For Norwegian scientists, the sounding rockets offered new unique opportunities for in situ ex- ploration of the aurora, and indeed the application of these tools rapidly provided a breakthrough in our scientific understanding of the phenomenon.

Secondly, ionospheric variations associated with the aurora have great practical consequences for radio communication and navigation systems. Before the space age, such systems depended to a large extent upon waves reflected from the ionosphere; in and near the auroral zone, rapid variations of reflection height, and scattering and strong absorption of the radio signals can cause severe problems. For example, strong absorption of high-frequency (HF) waves can wipe out communication for days and weeks, and the accuracy of low-frequency and very low frequency navigation systems such as LORAN-C and OMEGA can deteriorate significantly. Obviously, both civilian and military users needed new knowledge that could lead to better predictions of such disturbances and to mitigation of their effects, for example by development of new signal processing technology. The Norwegian Defence Research Establishment (FFI) was founded in 1946 and had carried out extensive ground-based 
experimental studies of radio wave propagation through the middle- and high-latitude ionosphere.

The first American satellite, Explorer-1, was launched in January 1958 and radically changed our views of the Earth's upper atmosphere and its transition into interplanetary space. Both scientifically and politically the time was ripe for scientific studies exploiting the opportunities offered by the development of the new space technology. In January 1960 the Norwegian Research Council for Science and Technology (NTNF) formed a space science exploratory committee, following an initiative taken by Finn Lied, director of FFI and professor Svein Rosseland of the University of Oslo. The mandate of the new committee (chaired by Rosseland) was to propose steps that should be taken to develop space science on a national basis and how, and to what extent, Norway should participate in international collaboration in the field. Two of the recommendations were that satellite and sounding rocket technology should be used for scientific purposes, and that a rocket range should be established in northern Norway. Such a range would attract foreign space scientists and thus stimulate international collaboration.

In 1960 Dr Bjørn Landmark of FFI and Dr S. Fred Singer, a US scientist from NASA, toured northern Norway to find a suitable location for a rocket range. Their recommendation was Andøya, an island in the Vesterålen archipelago. Here, only $6 \mathrm{~km}$ from the small town of Andenes at the northern tip of the island, they found a secluded bay backed by sheltering mountains and facing northwards towards the Norwegian Sea. The location $\left(69^{\circ} 17^{\prime} \mathrm{N}, 16^{\circ} 01^{\prime} \mathrm{E}\right)$ was advantageous for several reasons: it was in the centre of the night-time auroral zone, it had a very large downrange impact area to the north with little ship traffic, it was to a certain degree sheltered by the mountains from the winds, and it was close to the large military airfield at Andenes. The local name of the bay was Oksebåsen. This name may be interpreted as "the bull's pen", although its origin is uncertain. In any case Norwegian scientists chose to name their rockets after Ferdinand, the legendary peaceful bull who loved flowers, not fights. Thus, during the cold war, the point was made that the aim of the new Andøya Rakettskytefelt (legal name), or Andøya Rocket Range, was to conduct basic research for peaceful purposes.

A permanent Norwegian Committee for Space Research was established under NTNF in January 1961, and the payload for the first rocket, Ferdinand 1, was developed and instrumented as a Danish-Norwegian project. Contact with NASA was also made, and the total project was formalized by a trilateral agreement between NTNF, the Danish Ionospheric Laboratory and NASA. The project encompassed a series of eight sounding rocket launches, six from Andøya and two from Wallops Island. The first payload included a radio wave experiment to measure electron density and electron-neutral collision frequency in the lower ionosphere and instruments to determine the trajectory. In subsequent launches photometers and particle detectors were added. NASA supplied the telemetry on the ground and in the pay- loads. A two-stage rocket configuration, a Nike-Cajun, was chosen for the first launches. After a remarkably short and hectic time of preparation, on 18 August 1962 at 07:09 local time, Ferdinand 1 was successfully launched to an altitude of $101.5 \mathrm{~km}$. Norway had entered the space age.

\section{The early development of ARR}

Describing the facilities for the first rocket launch as primitive might be an understatement. NASA supplied a simple telemetry station. A small launcher was developed and built by the Christian Michelsen Institute (CMI) in Bergen. The firing panel, also supplied by NASA, was set up outdoors. It was, after all, summer! A few small buildings were set up. One of them is still in use. FFI was responsible for the launch, for the mechanical structure of the payload and for the trajectory determination. The experiments were developed by Danish and Norwegian scientists and engineers. Figure 1 shows the launcher with Ferdinand 1 and Egil Eriksen (FFI) at the launch panel.

In parallel, Professor Harald Trefall of the University of Bergen had established a launch and telemetry station for stratospheric balloons at Andenes. The first balloon for studies of cosmic radiation was launched just 1 month after the launch of Ferdinand 1. Later balloon campaigns could use the facilities at the rocket range.

From these simple beginnings, the systems were rapidly developed. In 1965 the activities were restructured. NTNF set up a new committee for space applications with subcommittees for space research and industrial space applications. A new NTNF department for space activities, NTNFR, was established. At Andenes, a new Norwegian-built telemetry station was ready in 1964, and NTNF took over the operation of the range.

The first operations were carried out by personnel from FFI and the universities, with valuable assistance from the military airbase, Andøya Flystasjon. Key people in this work were Bjørn Landmark, Egil Strømsø, Egil Eriksen and Jan Trøim from FFI, and Odd Dahl and Asbjørn Søreide from CMI. Soon there was an obvious need for permanent staff at the range. The numbers gradually increased, and in 1972 the staff numbered 18 people. From 1967 Arne Gundersen from NTNFR was head of ARR, a position he held until 1989, when he was succeeded by Kolbjørn Adolfsen.

In the years 1969 to 1970 , ARR changed significantly. A technical development was needed to accommodate larger rockets and more complex payloads. NTNF supplied a loan of NOK 4.5 million. The aim was to make the range attractive to potential users, so that an income could be secured. The investment included new buildings, new launchers and a new telemetry station. Figure 2 shows two stages of development of the infrastructure. 


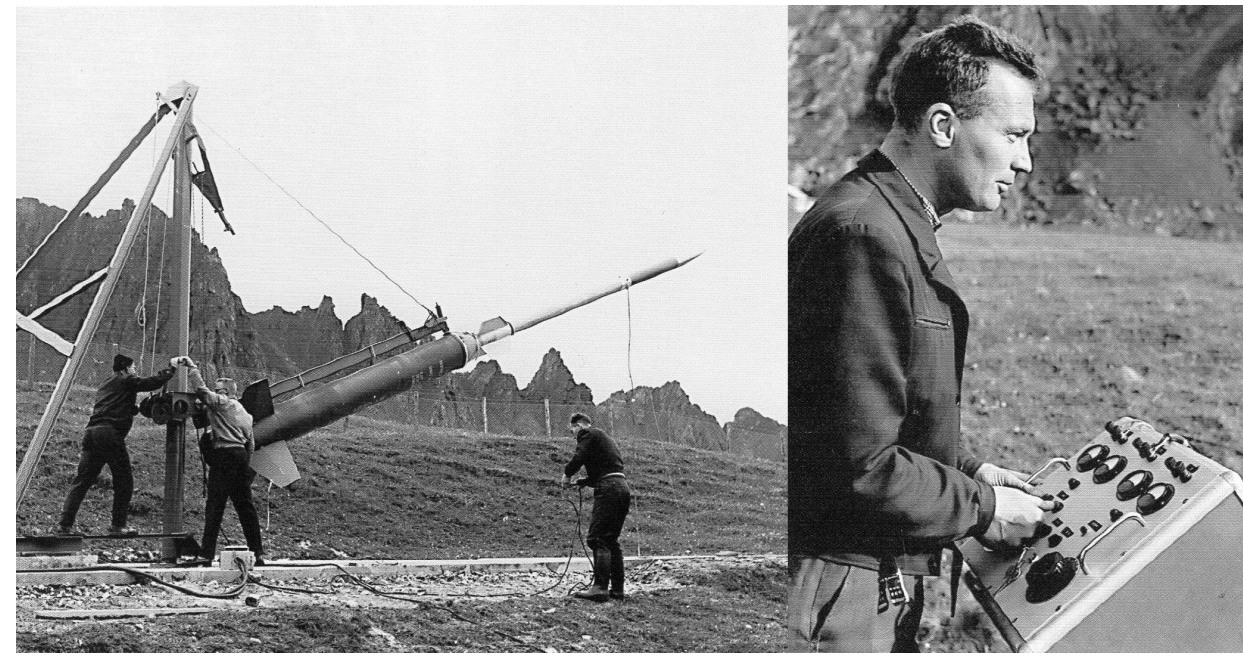

Figure 1. Preparations for the launch of Ferdinand 1.
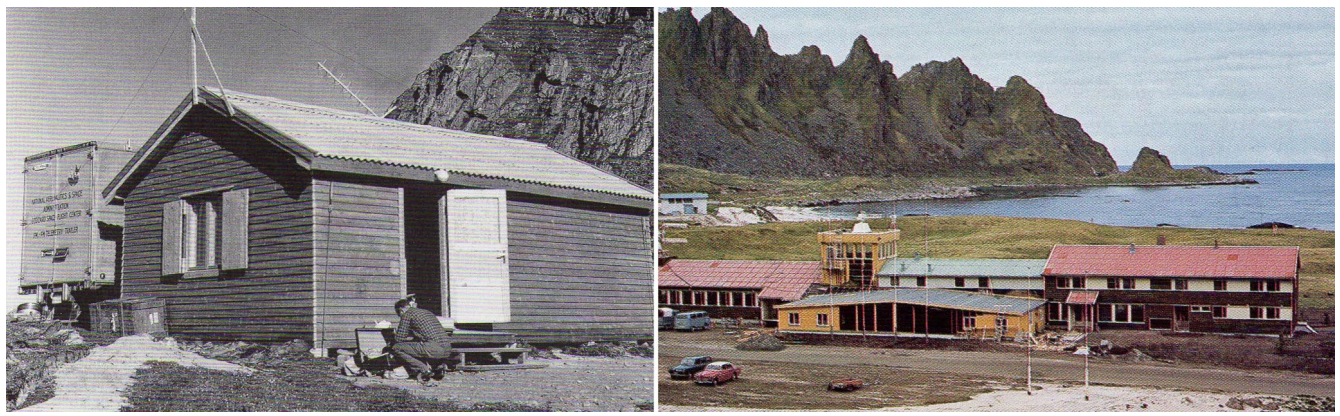

Figure 2. Buildings in 1962 and 1970.

\section{International collaboration}

The history of Andøya Rocket Range is an interesting example of how a small nation can make an impact in science and technology on the international scene. The space science exploratory committee saw the opportunities and acted swiftly. It was important to exploit the new technology. In auroral and ionospheric physics, Norway had the advantage of a solid scientific tradition, combined with a geographical position that offered unique opportunities for experimental studies. Instrumented rockets and satellites opened a window to a part of the atmosphere totally unexplored by in situ measurements. Even the simplest experiment could give new, and sometimes unexpected, results. No wonder that atmospheric and ionospheric scientists were eager to exploit the opportunities offered.

In the case of ARR, international collaboration was there from the start, through the trilateral agreement between NASA, NTNF and the Danish Ionospheric Research Laboratory. In 1960 the Scandinavian Working Group for Space Research was formed with participation from Sweden, Denmark and Norway. This group was important in the planning of future collaboration in Scandinavian sounding rocket research. Denmark and Sweden were members in the newly formed European Space Research Organisation (ESRO). ESRO had considered Andøya as its base for sounding rockets but decided that a site near Kiruna in Sweden was a better alternative. For this reason, Sweden did not participate in the first five rocket launches from ARR. However, the new ESRANGE was not operative until 1966, and Kiruna Geophysical Observatory, KGO, accepted an invitation to launch an instrument in Ferdinand 6. This was the start of a long-lasting Scandinavian collaboration that later included launches from both rocket ranges. ESRO launched three campaigns from ARR during the period 1966-1972. In 1972, ESRO discontinued its research using sounding rockets, but several member countries wanted to continue such research at high latitudes. The ESRANGE Special Project was launched as an agreement between Sweden on one side and Belgium, the Netherlands, France, Switzerland, the UK and Germany on the other. Norway was not an ESRO member but participated through a special deal with Sweden. The project included 40 weeks of operation per year from ESRANGE and ARR. 
In the early years, groups at FFI and the universities in Oslo and Bergen developed scientific and technological methods to study the ionosphere and upper atmosphere with sounding rockets. These skills, combined with the unique location and improved services of the ARR, turned out to be very effective in attracting partners from the international community, just as predicted by the first Norwegian space committee. Indeed, national and international collaboration has been essential for success. A large network of users gradually developed. Groups in the US, Austria, Germany, the UK, France and Scandinavia were particularly important in this context.

The key to success was to address a scientific problem by combining complementary skills, experience and resources of ARR and the different participating groups to form an effective campaign. The extensive German-Norwegian collaboration may serve as an example of how this system worked:

1. The scientists decided on a sounding rocket payload with a set of instruments needed to address a scientific problem area. A reasonable formula for the cost sharing between the participating groups was decided upon and formed the basis for applications to the national funding agencies.

2. The German Aerospace Center (DLR) supplied the rocket motor(s).

3. CMI was responsible for the mechanical structure of the payloads.

4. FFI was responsible for the telemetry and electrical integration of the payload.

5. ARR was responsible for the launch services.

6. Finally, the scientists jointly analysed the data and published the results.

This type of collaboration turned out to be very advantageous for ARR. It allowed the groups and organizations to specialize in scientific and technological disciplines and to combine these skills in an effective way. For the range, the challenge was to develop its services to anticipate and meet the requirements of the customers. NASA, DLR, CMI and FFI were particularly important partners in the technological development of range facilities. Interaction with all scientific groups using the range contributed to the knowledge and skills of the range personnel. A complete list of the customers of ARR/ASC would be very long and include groups from many European countries, as well as from the US, Canada and Japan (Thrane, 2003).

\section{Further development of ARR infrastructure}

Even though the development of the range facilities was a continuous process, a few important milestones should

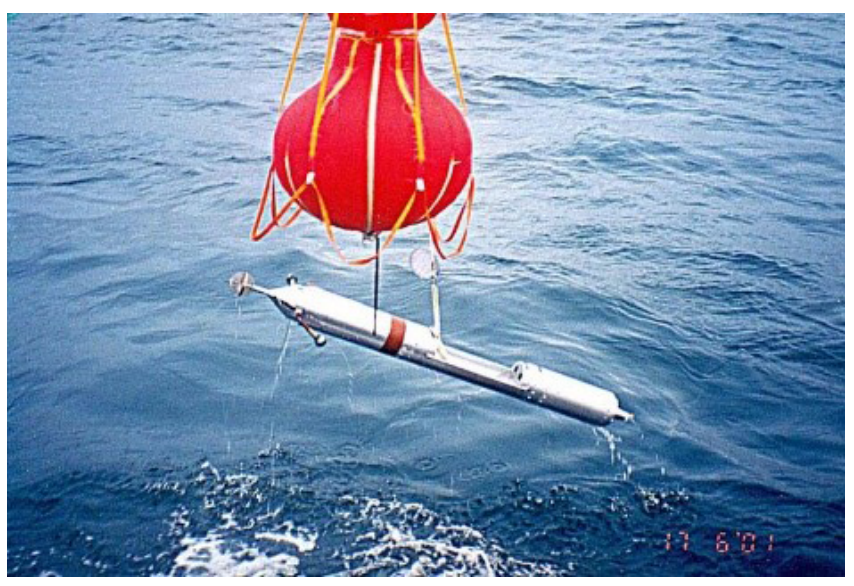

Figure 3. Recovery operation.

be mentioned. In 1976 the User Science Operation Centre (USOC) was finished. This will be described in Sect. 7.3. In 1989 Kolbjørn Adolfsen took over as head of ARR, and a new building with accommodation for visitors and a section for education was finished. Comfortable and convenient living quarters at the range made life much easier for participants in the campaigns. A new section for education marked a beginning for activities that will be described in Sect. 8. In 1996 a new launcher was delivered for rockets weighing up to $20 \mathrm{t}$.

In 1990 a system for sea recovery of smaller rocket payloads was developed in a collaboration between DLR, CMI and FFI. The system was first used in the GermanNorwegian TURBO campaign to study turbulence in the mesosphere (Lübken et al., 1998). The payloads were separated from the single-stage motors after burnout and carried a parachute and floatation bag system. They were picked up from the sea by a fishing vessel with the appropriate equipment. Some of the payloads were launched many times, saving construction costs and preparation time. One payload was, in fact, launched twice in $24 \mathrm{~h}$.

While Andøya is ideally situated for studies of the nighttime aurora, the Svalbard archipelago lies in the daytime part of the auroral oval. A rocket launch site at Svalbard would therefore offer new and unique opportunities for scientific investigation. After a few years of preparation, ARR opened a new rocket launch facility at Ny-Ålesund $\left(78^{\circ} 56^{\prime} \mathrm{N}, 11^{\circ} 51^{\prime} \mathrm{E}\right)$ in November 1997 . The first rocket, ISBJØRN 1, carried a Norwegian-built payload, and the campaign comprised two Norwegian and two NASA rockets. Svalbard Rocket Range (SvalRak) ushered in a new era in auroral and magnetospheric research.

For many years "Norwegian" rocket payloads were planned and built by the groups at FFI, CMI and the universities before they were brought to ARR for final testing and launch. Many of these rockets were one of a kind, with payloads developed for highly specialized studies. To cut costs 


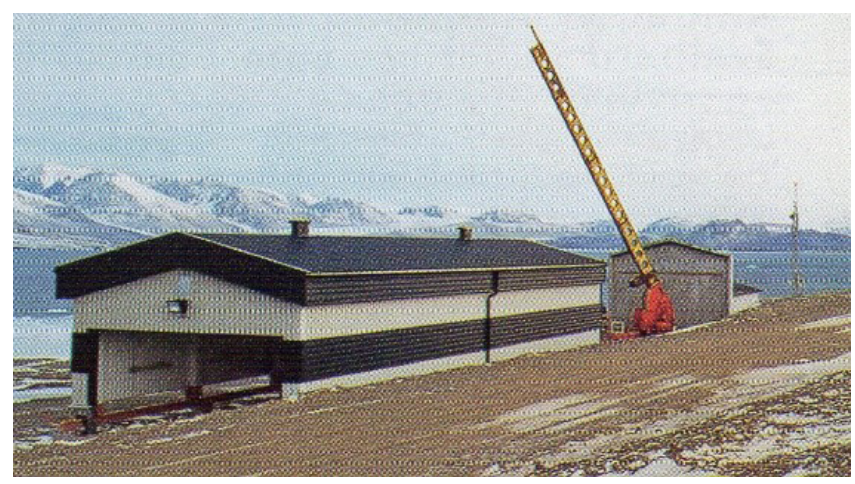

Figure 4. Ny-Ålesund launch site.

and development time, there was a need for a standardized payload that could easily be adapted to specific scientific investigations. It would also be advantageous if such payloads could be assembled and tested at ARR. Therefore, in collaboration with FFI and CMI, ARR introduced the "hotel payload" concept. This payload has standard basic functions, such as telemetry, mechanical structure, and power supply. The scientists can "rent" space for instruments in the "hotel" and specify the launch conditions. The technical expertise needed for mechanical and electronic integration of such payloads was gradually transferred from FFI and CMI to ARR. The first hotel payload was successfully launched from Svalbard in 2005, and today ARR has technical facilities in house needed for such services (https://www.andoyaspace. no/hotel-payload/, last access: 5 December 2018).

\section{The rocket launches}

The statistics of rocket launches from ARR and SvalRak provide an interesting overview of the life and times of the ranges. Figure 5 shows the number of instrumented rockets launched per year from 1962 to the present. The red columns show the total number; the blue columns show the number of rockets carrying payloads built by Norwegian groups. The first 10 years were particularly hectic, with an extensive use of the range by the international community, mainly under the umbrella of the ESRANGE Special Project and the collaboration with NASA. During the next 20 years the focus was on the middle atmosphere and lower ionosphere. Under the auspices of COSPAR (Committee for Space Research) and SCOSTEP (Scientific Committee for Solar-Terrestrial Physics) the Middle Atmosphere Programme (MAP) and Middle Atmosphere Cooperation (MAC) were organized. A series of important international campaigns were carried out in this context, and ARR played an important role. The campaigns are listed in Appendix A. The ARR facilities made it possible to launch many rockets in intensive, dedicated studies of selected ionospheric/atmospheric phenomena. The Norwegian scientists at FFI and the universities in Oslo,

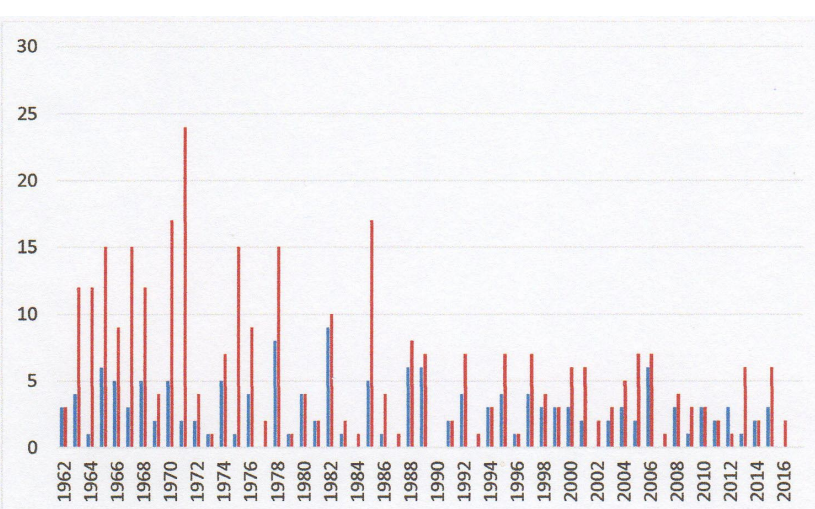

Figure 5. Total number of instrumented rockets launched (red columns) and number of payloads built in Norway (blue columns).

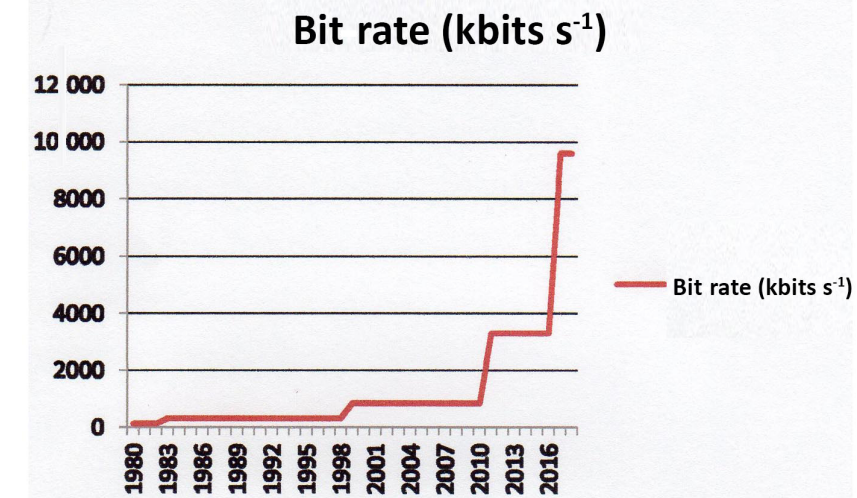

Figure 6. The development of the ARR telemetry capacity since 1980 (Courtesy of Tom Arild Blix FFI).

Bergen and later Troms $\emptyset$ built a significant number of payloads, as illustrated in Fig. 5.

FFI established a group that specialized in payload integration, and the mechanical structures were developed at CMI. In general, nearly all payloads launched from ARR carried instruments from different nations. A wide range of scientific problems were addressed. These could, in broad terms, be divided into two fields:

- in situ studies of ionospheric and auroral processes,

- in situ studies of the middle atmosphere and lower ionosphere.

The first field needed rockets with high apogees from $140 \mathrm{~km}$ to more than $1000 \mathrm{~km}$. 144 such rockets have been launched. For the second field, apogees of $100-140 \mathrm{~km}$ would be adequate, and the number of launches is 196. Figure 7 shows different types of trajectories that can be used from the two ranges. Several rockets have been launched from Andøya with apogees of about $1400 \mathrm{~km}$ over Svalbard and impacts far into the polar region. 


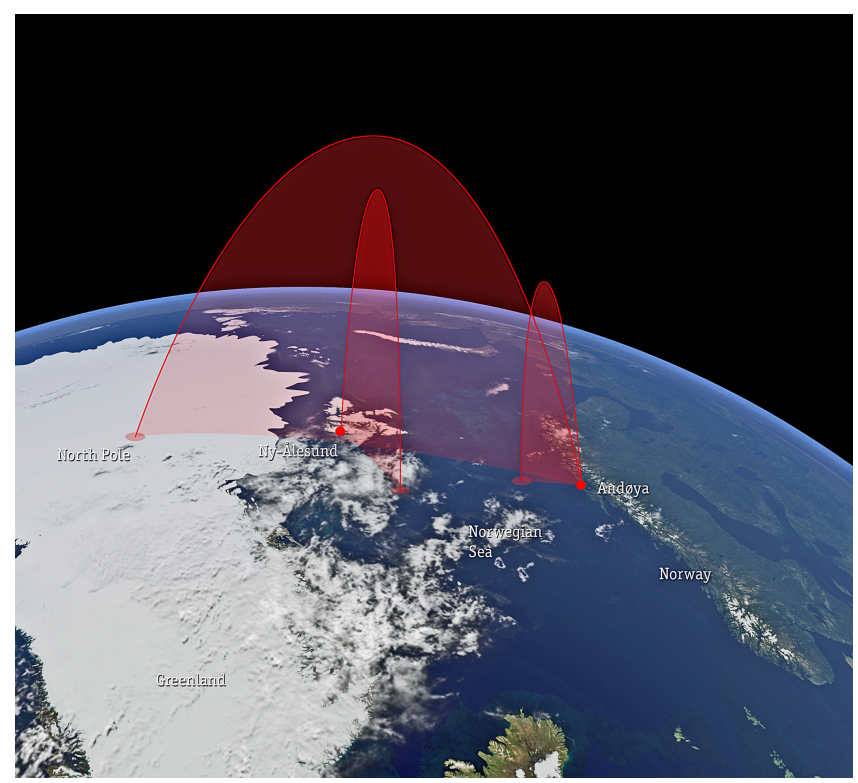

Figure 7. Types of rocket trajectories.

The high-altitude rockets in general carried more instruments and had longer flight times. Thus, from a scientific point of view, there has been a reasonable balance between the two, partly overlapping, research areas.

An important supplement to the instrumented rockets was the use of meteorological rockets. These were small, onestage rockets that reached altitudes of $100-110 \mathrm{~km}$. They carried no active instruments, but near apogee they released a falling sphere or a cloud of aluminium chaff. As the sphere or chaff fell through the mesosphere, their motion was tracked from the ground by radar, and wind, density and temperature profiles could be derived. A very powerful and advanced radar system was required, and an MPS36 radar was normally supplied by DLR. Figure 8 shows the number of meteorological rockets launched from ARR and SvalRak. The use of such rockets provided very valuable information for many years. Also, Professor Ove Havnes and his group at the University of Tromsø, with the help of FFI, developed instrumented mini-payloads that could be launched on the small rocket motors. This development was a real technical challenge because the payloads had to withstand tremendous acceleration and heat load during launch. The advantage was that the motors were cheap and the launchers small and portable. Some interesting measurements were made in the mesosphere with this technique (Mortensen et al., 1997).

Unfortunately, rocket motors of this type are no longer available.

As stated earlier, ARR was always dedicated to the peaceful exploration of space, with sounding rockets as its most important tools. Nevertheless, a curious incident made news headlines all over the world and made ARR famous overnight. On 25 January 1995 at 06:24:08 UT a Black

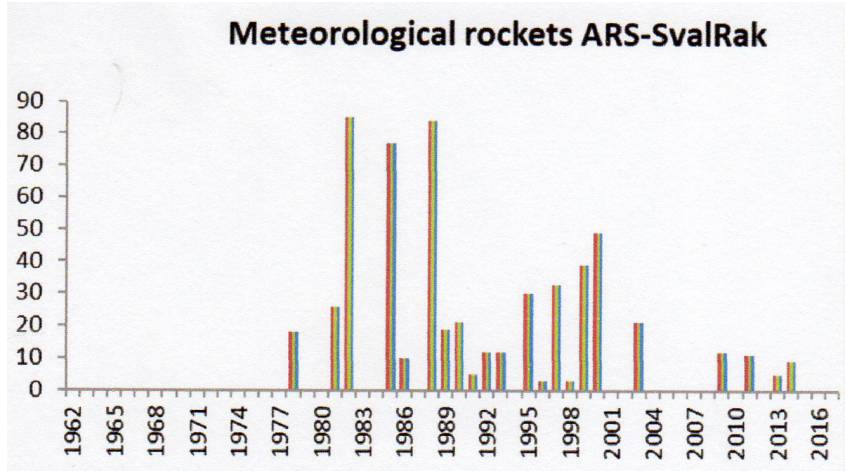

Figure 8. Total number of meteorological rockets launched.

Brant B XII four-stage sounding rocket was launched from Andøya. The payload reached an apogee of $1364.5 \mathrm{~km}$ and landed well north of Svalbard. This was the largest sounding rocket launched from the European mainland. However, Russian news media reported that the Russian armed forces had identified it as a possible enemy missile heading for Russia. President Yeltsin confirmed that he had opened his "black briefcase" to be used for enabling a nuclear attack. Of course, the trajectory was nowhere near Russian territory, and ARR had given the Russians prior notice according to established routines. Still, the incident was a reminder that space exploration can be a politically sensitive issue (Collett, 1995).

Figure 5 shows that since the late 1980s the annual number of launches has been quite stable, between two and seven. This indicates that the scientific interest in using rockets as well as the available funding has been stable. However, in terms of scientific results, just counting the number of launches is misleading. There has been a continual technological development allowing a miniaturization of electronic circuitry, detectors and mechanical components. Thus, the payloads can carry more instruments with ever-increasing data sampling rates. This means improved capabilities to study fine-scale variations of atmospheric parameters in time and space. This development must be matched by increased telemetry rates in the payload and on the ground. The capabilities of the ARR telemetry services can therefore serve as a rough measure of the scientific yield. Figure 6 shows that the information flow from a rocket payload has risen dramatically in the last 2 decades.

As will be discussed in Sect. 11, the sounding rocket launches from ARR/ASC have provided very important scientific results. In addition, planning, building and launching the payloads have been essential for training scientists and technologist in general space science. A sounding rocket project can be implemented in a short time period and is therefore well suited for master's and PhD students. Launching a satellite is much more expensive and time consuming. Implementation of a sounding rocket programme is therefore an important part of space education. 


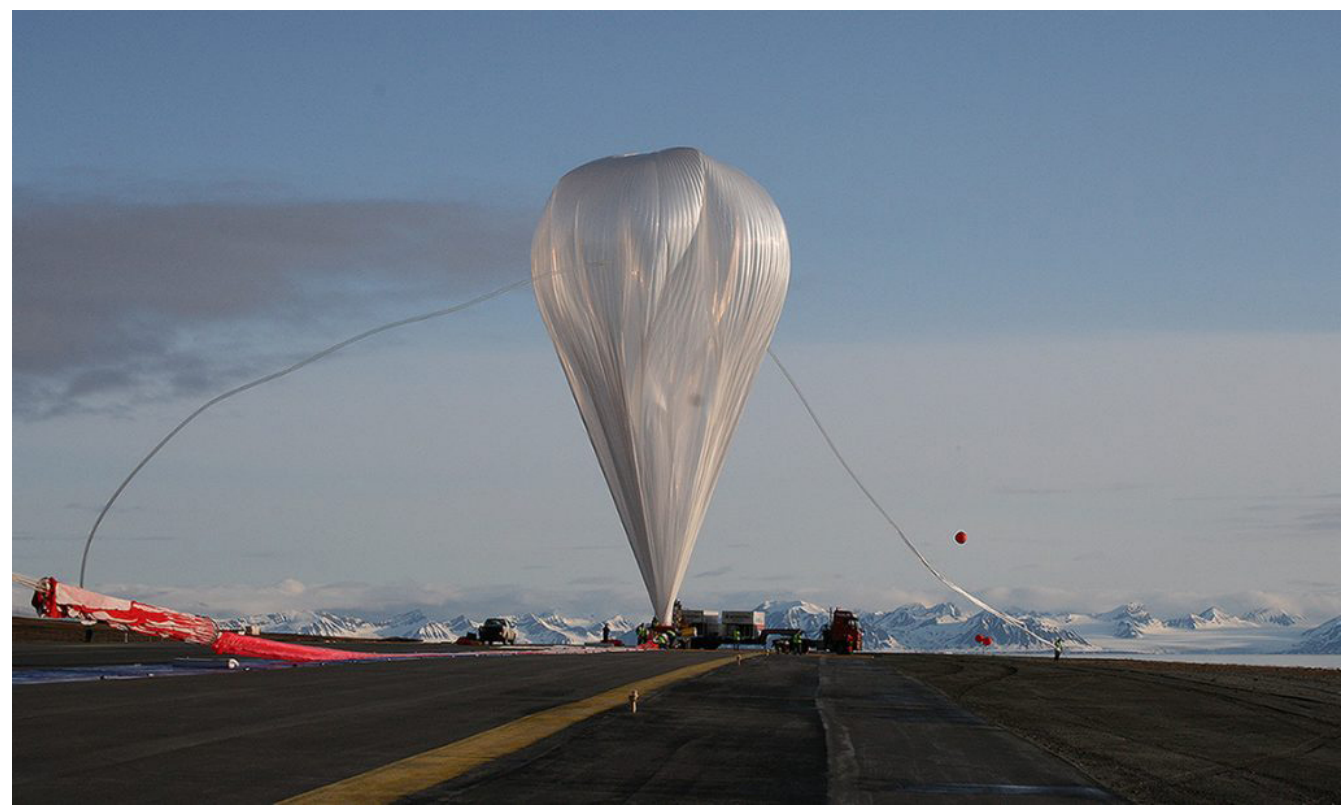

Figure 9. Balloon launch from the airfield at Andenes.

\section{The balloons}

In the early 1960s a research group was established at the University of Bergen to study solar cosmic radiation with stratospheric balloons. In 1962 the first balloons were launched from Andenes and Bergen. This activity provided important information on the morphology of the precipitation of solar energetic electrons by measuring bremsstrahlung Xrays produced by the precipitation (Bjordal et al., 1971). The balloons were typically $5000-37000 \mathrm{~m}^{3}$ and floated in the height region $35-40 \mathrm{~km}$. In summer, the balloons would drift towards Greenland and Canada. In winter they drifted eastwards towards Sweden, Finland and Russia. The instrument payloads were taken down in parachutes for reuse in new balloons. Figure 9 shows one of the largest balloons launched from Andøya.

The state and development of the stratospheric ozone layer was studied by launching small instrumented balloons from Andøya. This project was started in 1995 and was part of the French balloon programme led by Professor Jean-Pierre Pommereau (https://www.researchgate.net/ profile/J-P_Pommereau, last access: 5 December 2018).

\section{Ground-based scientific instrumentation.}

A sounding rocket provides a detailed snapshot of selected physical parameters along the trajectory. There is obviously a need for monitoring the time development of the state of the upper atmosphere before, during and after the launch. Ground-based and satellite measurements are needed to determine the optimum launch conditions and to interpret the rocket measurements. At the very beginning a riometer and a magnetometer were the only instruments available at the range itself for determining the optimum launch conditions. The Auroral Observatory in Troms $\varnothing-120 \mathrm{~km}$ east of the rocket range, with its complement of optical, radio and magnetic measurements - could assist, but there was no real-time transfer of data except by telephone. In addition, the experimenters would bring their own support instruments, such as all-sky cameras and auroral spectrometers. Gradually, ARR, in close collaboration with its customers, built up a groundbased scientific infrastructure that could provide better determination of the launch conditions, as well as easier and more precise interpretation of the data from the rocket-borne probes. In the following we shall briefly review the development of this important part of the ARR activities.

\subsection{Arctic Lidar Observatory for Middle Atmosphere Research (ALOMAR)}

The development of laser technology offered new opportunities for atmospheric studies. A lidar (light detection and ranging) is an instrument that uses pulsed laser beams. The light pulses are launched into the atmosphere and are scattered back from air atoms, molecules and particles. Analysis of the returned signals yields a host of detailed information about the state of the atmosphere up to a height of about $110 \mathrm{~km}$. In 1984 Prof. Ulf von Zahn and his group at Bonn University (BU) established the first lidar at ARR in a small building at the range and found that the technique was a very powerful tool for studies of the middle atmosphere despite the variable weather conditions in the Arctic winter.

In 1991 Prof. von Zahn (later director of the Institut für Atmosphärenphysik (IAP) in Kühlungsborn) contacted FFI 


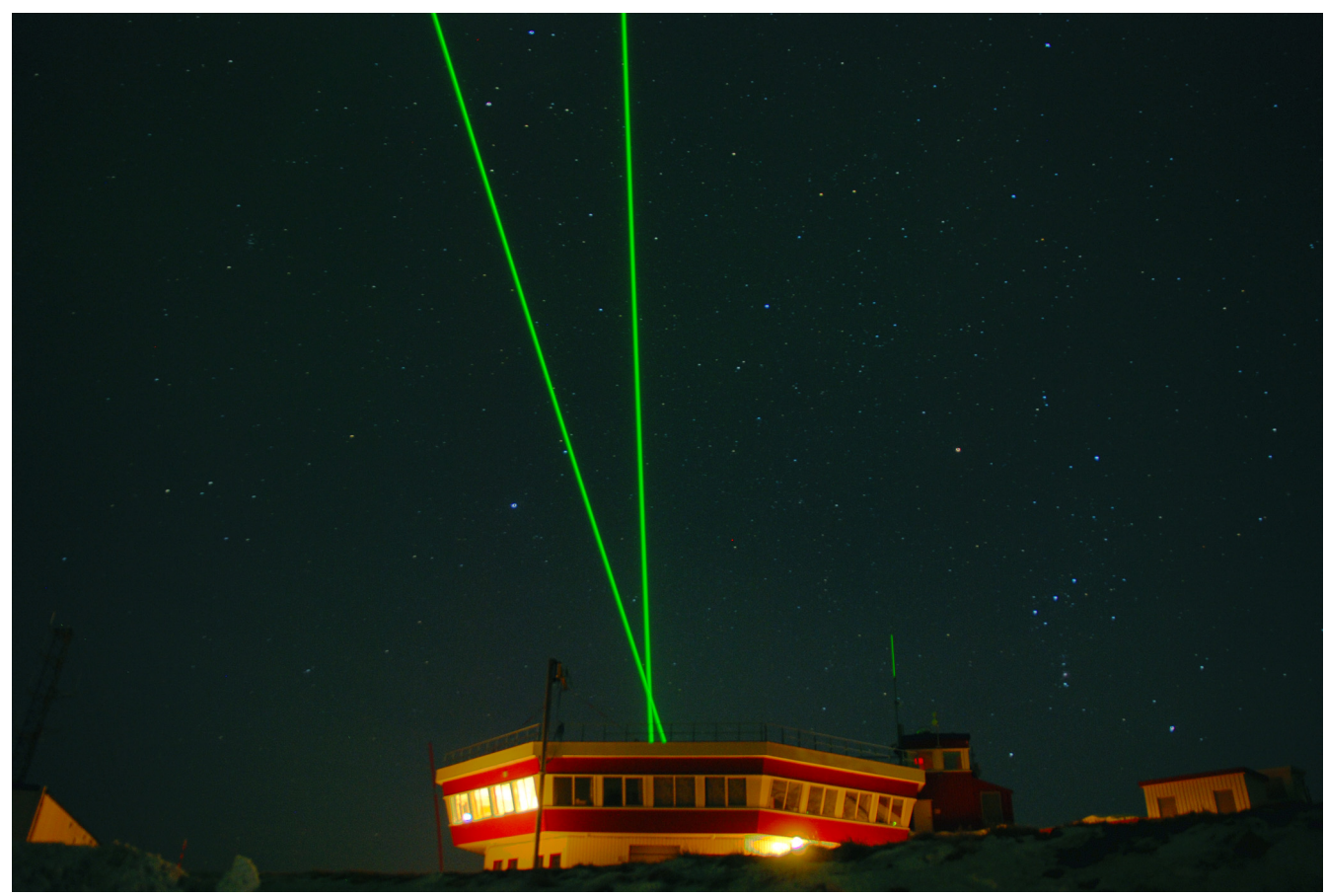

Figure 10. ALOMAR, the most important ground-based observatory at ARR/ASC. Two laser beams are visible.

(Eivind Thrane) and ARR (Kolbjørn Adolfsen) with the message that he could obtain two large high-quality astronomical mirrors and that he proposed to build a lidar observatory at ARR. A German-Norwegian working group was quickly established, and a site on the mountain Ramnan near the range was selected for the observatory. The location was chosen because it had an unrestricted view of the sky and because the sensitive optical instruments were away from the salt and sand spray from the beaches. The building was financed through Norwegian sources, and the first instruments were a complex German Rayleigh-Mie-Raman (RMR) lidar using the two steerable mirrors, and a Norwegian ozone lidar. However, soon other scientific groups joined. ALOMAR was established as an international observatory and was opened in 1994, only 3 years after its inception (see Figs. 10 and 11; https://www.iap-kborn.de/home/, last access: 5 December 2018).

The lidars soon proved to be very useful during rocket campaigns, also because they could determine atmospheric conditions along, or close to, the rocket trajectory. However, ALOMAR has been a great success, not only in support of rocket launches but also as a unique instrument for studying the middle atmosphere. Now, ALOMAR is a department of Andøya Space Center, and all the ground-based scientific infrastructure belong in this department. From 1993 to date 490 scientific articles have been published based upon ALOMAR-related measurements. Please see the following links for more information: https://www.iap-kborn.de/ en/research/publications/alomar/ (last access: 5 Decem- ber 2018), https://www.andoyaspace.no/alomar-observatory/ (last access: 5 December 2018), https://www.iapkborn.de/forschung/abteilung-optische-sondierungenund-hoehenforschungsraketen/instrumenteundmodelle/ (last access: 5 December 2018).

\subsection{The radars}

Remote-sensing radars are important for studies of the ionosphere and upper atmosphere and are very useful in combination with in situ rocket experiments. In 1978 the first realtime data transmission from the partial-reflection mediumfrequency radar at Ramfjord near Troms $\varnothing$ to ARR was carried out during a rocket campaign. This radar was operated by the University of Troms $\varnothing$. The data provided real-time information on the electron density profile in the $D$ region and on the presence of irregularities/turbulence in this region. The availability of such data proved to be very useful; in fact, two rockets were successfully launched during the test countdown! In 1981, the European Incoherent Scatter Facility (EISCAT) radar started operations, also at Ramfjord. This facility could monitor the state of the ionosphere over a wide height range and could provide valuable assistance to ARR in the determination of launch conditions. In 1996 the EISCAT site at Svalbard was inaugurated with two incoherent scatter radars near Longyearbyen. When the first rockets were launched from Ny-Ålesund in 1993, these radars were being tested and provided valuable information on the state of the ionosphere (https://www.eiscat.se/, last access: 5 December 2018). 


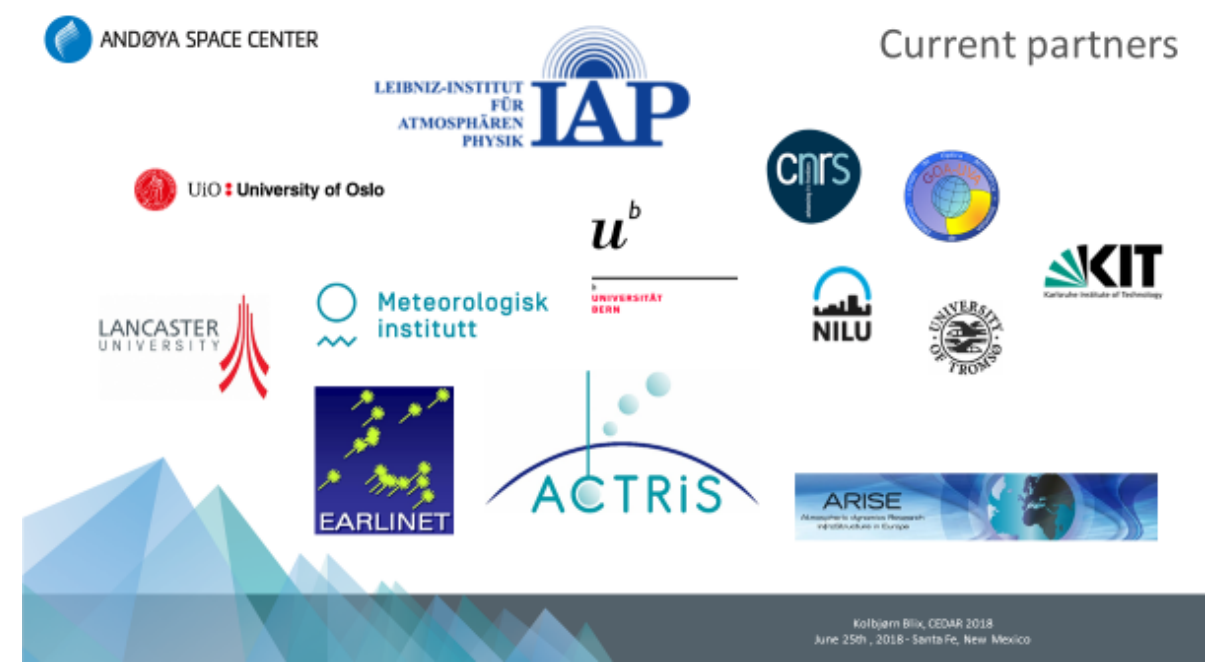

Figure 11. The present partners in ALOMAR.

During the MAP/WINE (Winter in Northern Europe) campaign in the winter of 1983/84, a mobile very high frequency (VHF) radar was used at ARR for the first time to study the dynamic properties and detailed structure of the middle atmosphere (see references in Appendix A). As the science and technology of atmospheric radars were further developed, this radar was replaced by the ALWIN and later the MARSSY radars (Fig. 12).

In addition, two MF (partial-reflection) radars and a meteor radar were installed near the range.

\subsection{User Science Operation Centre (USOC)}

In 1978 ARR established an operation centre for the users. In a separate building, relevant information from the groundbased instruments was collected and displayed so that the scientists could have easy access to the available scientific information needed to determine the optimal launch conditions. USOC was modernized in 1995 and then again in 2005 with more modern screen projection techniques. Finally, it was moved to the main building in 2012. It is now a very sophisticated facility with Internet access to information the customer wishes to display (Fig. 13). The situation during a countdown is often complex and hectic, and the new USOC significantly enhances the chances of success.

The unique possibility for combining real-time measurements by scientific instruments on sounding rockets, satellites and the ground has been and is a very valuable asset that ARR/ASC can offer its customers, the scientists. Figure 14 gives an overview of the infrastructure.

\section{Space education}

Andenes is a small community located at the northern tip of the island of Andøya. Fishing and the fishing industry are important, and the military airbase also provided jobs and a source of income for the inhabitants. The establishment of ARR only $6 \mathrm{~km}$ from the village centre soon proved to be important for the community. The work at the range and at the airbase required personnel with training and skills in technology, and it would seem reasonable that the local high school should teach elementary courses in this field. It was important to interest young people so that they could study and qualify for exciting job opportunities in the local society. In 1988 the high school at Andenes, in collaboration with ARR, started work to include a course in space technology in the formal school curriculum. At a more advanced level, ARR was also in contact with Narvik University College, where courses in space technology at university level were initiated.

At a national level, Norwegian space activities were increasing rapidly and the need for recruitment was evident. At ARR it was realized that the facilities at the range, combined with the skills of the competent staff, offered unique opportunities for education in space science and technology. On 7 July 2000, NAROM (National Center for Space-related Education) was formally established. It was situated at and owned by ARR and received annual funding from the Norwegian government. Its purpose was to use the scientific infrastructure and activities at ARR to stimulate interest in space science and technology from elementary school to university level. This is accomplished through a very active programme with a series of courses and "space camps" for both Norwegian and international students and teachers. NAROM includes a visitor centre, Spaceship Aurora, that targets students, teachers and the general public. Today NAROM has a staff of 18 people and an annual budget of about NOK 18 million.

It should also be mentioned that ARR supported the rocket named ESPRIT, where US and Norwegian undergraduate students could build instruments for a full-sized payload to 


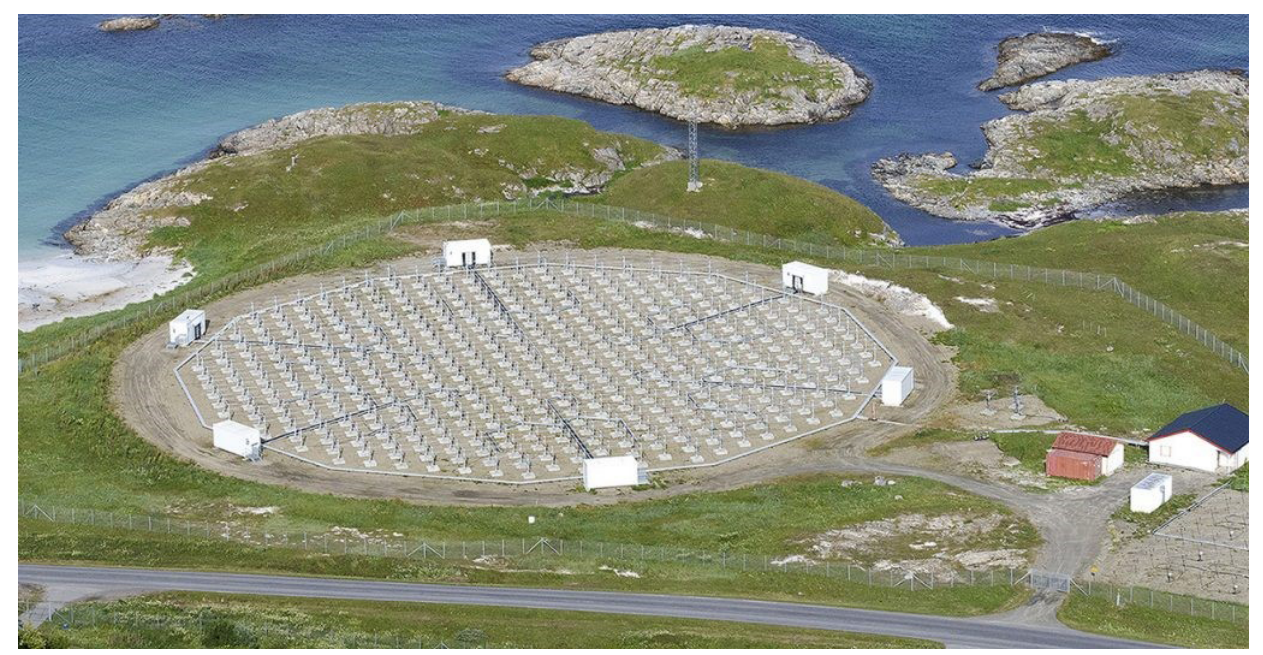

Figure 12. The MARSSY radar built by IAP. It is one of the most advanced instruments of its kind (https://www.iap-kborn.de/forschung/ abteilung-radarsondierungen/, last access: 5 December 2018).

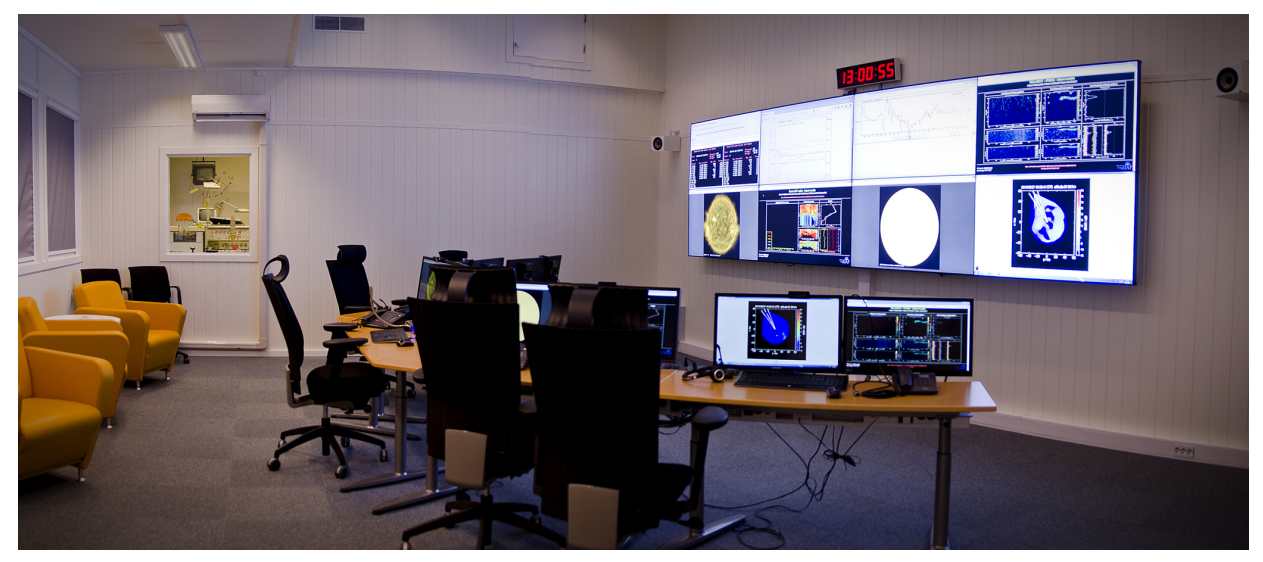

Figure 13. The science operation centre (USOC).

study the mesosphere and lower ionosphere. ESPRIT was successfully launched from ARR on 1 July 2006 (https: //www.andoyaspace.no/space-education/, last access: 5 December 2018).

\section{Andøya Test Center (ATC)}

The technological capabilities of ASC were also strengthened by the establishment in 2003 of the Andøya Test Center (ATC), a department that can test rockets, missiles and unmanned airborne systems for the Norwegian Armed Forces as well as for Norwegian space and defence industry (https://www.andoyaspace.no/test-range/, last access: 5 December 2018).

\section{The role of ARR on the national scene}

For many years ARR was part of NTNFR, the Norwegian Research Council for Technology and Science, department for space activities. In 1987 Norway finally became a full member of the European Space Agency (ESA), and the Norwegian Space Centre (NSC) was established under the Ministry of Industry. Pål Sørensen was its first director. The new centre was given wide responsibility for Norwegian space activities. ARR was established as a private company, owned $90 \%$ by NSC and $10 \%$ by Kongsberg Defence and Aerospace. In 2005 Kolbjørn Adolfsen retired as director of ARR and was succeeded by Odd Roger Enoksen. Enoksen had wide experience in politics as an MP, as leader of the Senterpartiet and as a cabinet minister. He took a leave of absence from ARR for 2 years to serve as minister for the Department of Oil and Energy. During this period Torstein Rødseth served as director. In 2014 ARR changed its name to Andøya Space Center (ASC). The name change reflected the fact than the activities at Andøya now comprise much more that the launch of scientific rockets. ASC is now a limited company owned $90 \%$ by the Ministry of Trade, Industry and 


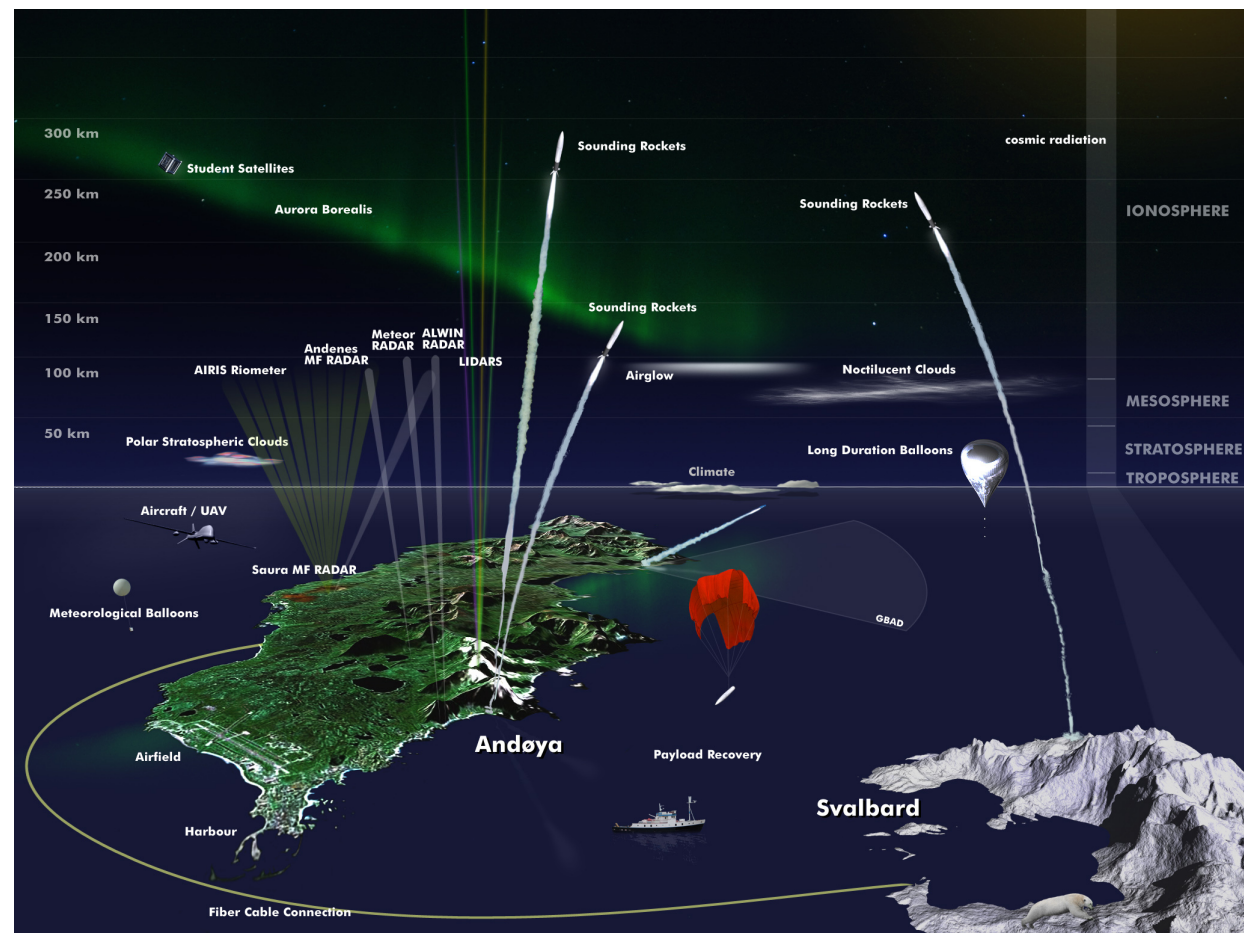

Figure 14. Overview of the infrastructure of ARR/ASC with SvalRak.

Fisheries and $10 \%$ by Kongsberg Defence and Aerospace. At present, ASC has an annual turnover of about NOK 150 million and a staff of 95 people. The development of ARR/ASC is illustrated in the linked video, which shows scenes from 1962 and 2017 (https://doi.org/10.5446/38276, Abrehemsen, 2017).

The home page of ASC is https://www.andoyaspace.no (last access: 5 December 2018).

\section{The scientific impact of ARR/ASC}

During 56 years of operation, ARR/ASC has established itself on the international scene as a leading base for scientific exploration of the Arctic ionosphere and upper atmosphere. I shall in broad terms point out some significant scientific results obtained by the users (4 321 fire!, 2002). A key to the success is the unique location of ARR/ASC including SvalRak. Typical apogees for sounding rockets can range from 120 to $1500 \mathrm{~km}$. Because of air drag, a rocket-borne probe cannot normally be exposed to the atmosphere below about $50 \mathrm{~km}$. This is therefore an effective lower height limit for such studies. The large impact areas for both ranges makes it possible to perform in situ measurements in a range of latitudes from $69^{\circ} \mathrm{N}$ to more than $80^{\circ} \mathrm{N}$ and from about $15^{\circ} \mathrm{E}$ to $10^{\circ} \mathrm{W}$ in longitude (see Fig. 7). Advanced ground-based and satellite instruments can also monitor the state of the atmosphere in, as well as below and above, this region and thus support the sounding rocket studies.
It is convenient to discuss the ARR/ASC results in two, partially overlapping, height regions, as described in the following subsections.

\subsection{The Arctic mesosphere and lower thermosphere, $50-120 \mathrm{~km}$}

Before rockets became available, very little was known about this height region, and it was sometimes referred to as the "ignorosphere". Ground-based studies of radio wave reflection and absorption had, to some extent, mapped the plasma in the high-latitude ionospheric $D$ and $E$ regions, but with poor time and spatial resolution. Also, there was little information about the state of the non-ionized air. Such information was badly needed to understand the atmospheric physics and chemistry, so that comprehensive atmospheric models could be developed. Rocket and ground-based studies from ARR/ASC have provided a wealth of information, such as listed below:

- Detailed knowledge has been obtained of the complex structure of the electron density as well as the positiveand negative-ion density in the Arctic lower ionosphere. A deeper understanding has been reached on how this structure is related to auroral activity (Friedrich, 2016).

- The lower ionosphere is only weakly ionized, and it is important to measure the composition of the non-ionized gas. Rocket-borne mass spectrometers and ground-based lidars have revealed a very complex and 


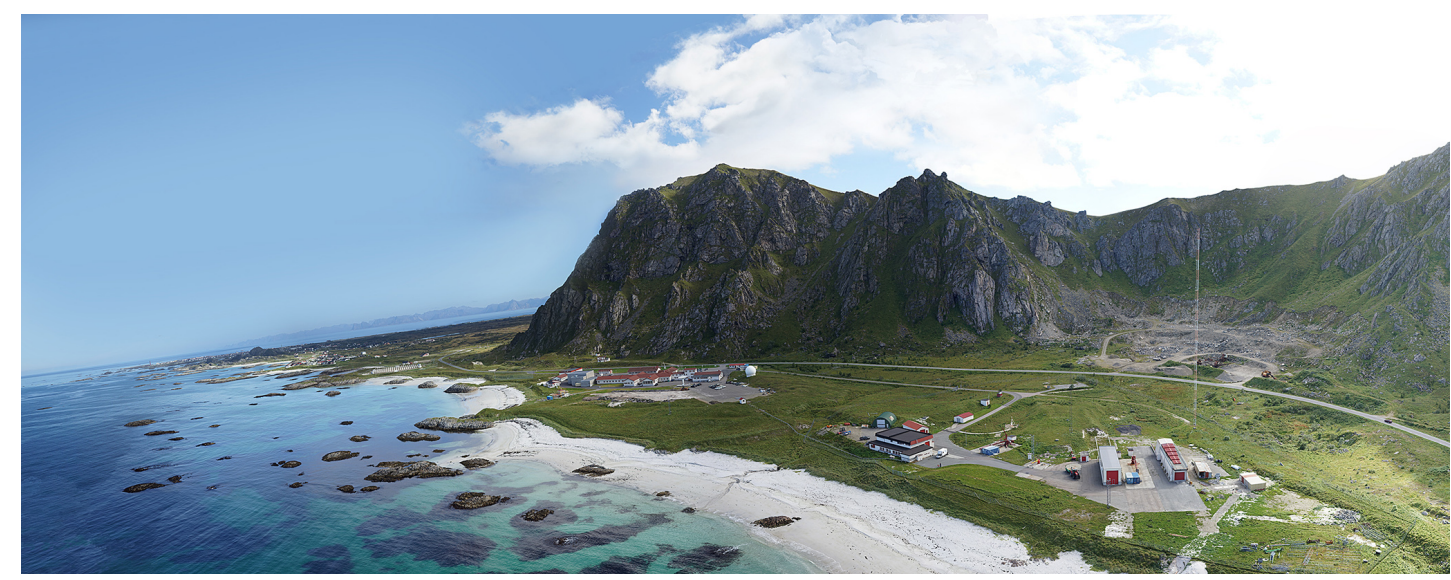

Figure 15. Panoramic view of ASC. Main buildings to the left, launch area to the right.

intricate chemistry where minor constituents play important roles.

- The weather and climate of this region has been studied systematically from Andøya with in situ and groundbased techniques. As an example, mapping of the annual variation of the temperature profile has led to an understanding of the cause of the deep temperature minimum in the Arctic summer mesopause near $90 \mathrm{~km}$. Pioneering and systematic studies of wind, waves and turbulence have been carried out from ARR/ASC and represent a breakthrough in our understanding of the dynamical processes in non-ionized gas (Lübken et al., 1998). These experiments include studies of the turbopause, that is, the transition near $100 \mathrm{~km}$ from a lower turbulent regime to a higher regime with laminar flow.

In the mesosphere and lower thermosphere, meteoric dust and ice particles are important constituents, and in summer they can be observed as noctilucent clouds and polar mesospheric summer radar echoes. In recent years weak layers have also been observed in winter. Research from ARR/ASC has significantly increased our knowledge of the microphysical processes of these phenomena and mapped their annual variations.

- (See references in Appendix A and in https://www. iap-kborn.de/home/, last access: 5 December 2018).

\subsection{The auroral thermosphere/ionosphere, $100-1500 \mathrm{~km}$}

Auroral phenomena had been studied from the ground by cameras and spectrometers, by magnetometers, by radio echo techniques and by riometers monitoring the ionospheric absorption of cosmic radio noise in the VHF band. These techniques were available in northern Norway and could be used by the "rocket scientists" to map the general background and time development of an auroral event and thus diagnose the optimum conditions for a rocket launch. The first rocket payload designed to study the aurora was flown from Fort Churchill in Canada in 1958 by the US Naval Research Laboratory (NRL). The first "auroral" rocket (Ferdinand III) was launched from ARR on 11 December 1962, and on 2 December 1997 the first rocket was launched into the cusp from SvalRak in Ny-Ålesund. A total of about 150 instrumented rockets have so far been launched into the auroral ionosphere from ARR/ASC and SvalRak. Some examples of the scientific achievements are as follows:

- The height variation of electron density as well as ion density and composition in the auroral $E$ and $F$ regions have been measured in situ.

- Energetic electrons and protons precipitating from the magnetosphere create the aurora. The energy spectra of these particles have been studied in situ, mapping their spatial and temporal variations.

- The spectra of auroral light emissions resulting from the energetic particles have been measured in situ, leading to much better knowledge of their variation in time and space. Rockets have been launched to large altitudes to map the geographical extent of an arc from above.

- New detailed knowledge has been obtained of the electric and magnetic fields within an aurora, and of the electric currents they produce (Pfaff et al., 1998)

- A spacecraft flying through the auroral plasma will interact with the medium, causing electric charging of the craft and changes in the surrounding plasma. Such processes are very complex and understanding them is essential for the interpretation of the results from the onboard instruments. These problems have been studied from ARR using payloads that are split during flight into a "mother" and a "daughter" payload. The mother and daughter will slowly drift apart to measure small-scale 
variations at two points in space. Part of the time they were connected by a tether to measure potential difference due to charging. Artificial aurora was created by launching a beam of energetic electrons from one of the payloads (Mæhlum et al., 1980).

- There are a several observatories and rocket ranges in the Arctic that have contributed to our knowledge of the aurora. Examples are ESRANGE in Sweden, Fort Churchill in Canada and Poker Flat Research Range in Alaska. However, in one field of science ARR/ASC offers unique advantages. The polar cusp is a region where the magnetospheric plasma has direct access to ionosphere. The particle flow in the cusp creates the daytime aurora, which is visible to the naked eye during the Arctic winter only on Svalbard and Franz Josef Land. Sounding rockets both from Andøya and from Svalbard can reach into the cusp for detailed studies of the coupling between the solar wind and the ionosphere. Such studies are supported by HF backscatter radars in the Arctic, by the EISCAT radars on the mainland and at Svalbard, and by satellites in near-polar orbits. Since 1997 only a few rocket campaigns have been carried out, but these campaigns have yielded new fundamental information about the processes in the cusp. The measurements cover a wide range of scales in time and space. For example, plasma structures and instabilities have been mapped with surgical precision down to scales of metres and seconds (Moen et al., 2012; Oksavik et al., 2012; https://www.sscspace. com/ssc-worldwide/esrange-space-center/, last access: 5 December 2018; http://www.pfrr.alaska.edu/content/ welcome-poker-flat, last access: 5 December 2018; http://www.astronautix.com/f/fortchurchill.html, last access: 5 December 2018).

In conclusion, 56 years of research using ARR/ASC and its facilities has made a very significant contribution to our knowledge of the Arctic upper atmosphere and ionosphere. The space age gave us efficient tools to explore the interaction between the solar wind, the Earth's magnetosphere and the upper atmosphere by new in situ measurements of the aurora borealis. Another important, and related, topic has been the exploration of the mesosphere (formerly the "ignorosphere"), where a combination of in situ and remote measurements has been very successful in describing and understanding the processes in this transition zone between the lower atmosphere and space. The results of this extensive research have been documented in high-quality scientific journals. The number of articles is large and difficult to estimate, but, as mentioned earlier, an example is the ALOMARrelated research that has resulted in close to 500 publications in the 25 years ALOMAR has existed.

A list of publications from this field may be found at https: //www.iap-kborn.de/home/ (last access: 5 December 2018).

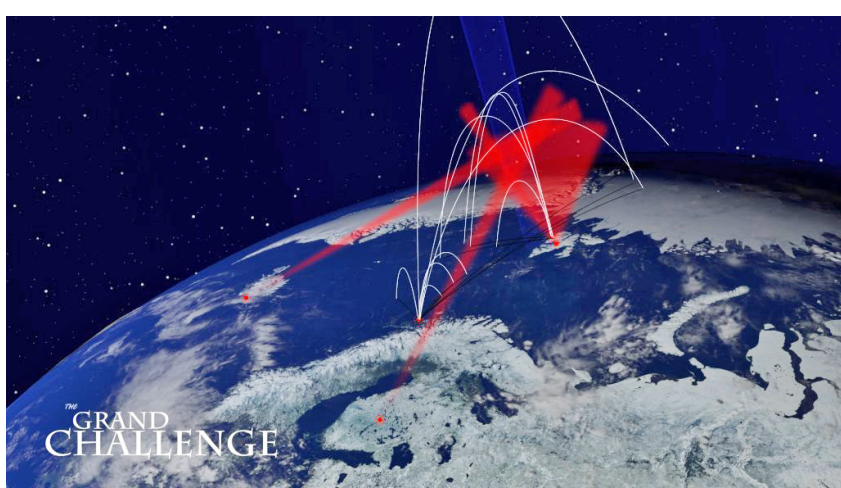

Figure 16. Sounding rockets and radars will explore the cusp region (https://www.andoyaspace.no/the-grand-challenge-initiative/, last access: 5 December 2018).

\section{The future}

Space science and the space industry are very important for Norway, and the NSC is a government agency under the Ministry of Trade, Industry and Fisheries. NSC is responsible for organizing Norwegian space activities. These had a total budget in 2014 of NOK 879 million (https://www.romsenter.no/ eng/, last access: 5 December 2018).

Andøya Space Center has become a very active company focussed on space activities. It is important internationally, nationally and for the local community of Andenes. A wide range of tools are available at ASC for scientists and engineers trying to understand and exploit the Arctic upper atmosphere. Sounding rockets are effective tools, and there are specific plans for new programmes. One of these is the Grand Challenge Initiative (GCI). Here, Norway has taken the lead in a collaboration between Norwegian and US research groups and agencies. GCI is a large-scale international collaboration targeting advancement in specific, fundamental issues in space and earth sciences. "The GCI Cusp Project is designed to advance the common understanding of cusp region space physics through coordinated experimental and theoretical research using ground-based instruments, modelling, sounding rocket investigations, and satellite-based instruments. GCI - CUSP consists of 8 missions with a total of 12 sounding rockets. International student participation through space plasma model development and a dedicated student rocket (G-CHASER) is an essential aspect of the GCI concept." (Jøran Moen, Department of Physics, University of Oslo, personal communication, 2018) (see Fig. 16).

A new Grand Challenge project from around 2023 is already being prepared; the GCI Mesosphere project is intended to utilize several launch sites in the Arctic and the tropics, as well as applicable ground-based sites. The aim is to include scientists and technologists from Norway, Sweden, Germany, the USA, Japan and other countries.

Another important future development is to build a launch site for small satellites in near-polar orbits. There is a Eu- 
ropean market for such services, and ASC and Norwegian authorities are seriously considering the possibilities. If implemented, these plans would mean a significant investment in technical facilities, buildings and staff. The launch site can not be built in Oksebåsen, so other locations on the island of Andøya will be evaluated.

\section{Summary}

The article reviews the history of Andøya Rocket Range, now Andøya Space Center, from its inception to the present. From a modest start in 1962 with the launch of the first rocket, Ferdinand 1, ARR/ASC has developed into a very active company with a staff of 95 and an annual turnover of about NOK 150 million. The focus has been on the scientific exploration of the Arctic ionosphere and middle atmosphere, and gradually a very sophisticated scientific infrastructure was developed in close collaboration with the international scientific community. This infrastructure comprises many groundbased instruments and includes a launch site at Svalbard. The activities at ARR/ASC have over the years been expanded to include space education and support of the Norwegian space industry. The future possibility of launching small satellites from Andøya is currently being explored. ASC is well established as an important observatory and company on both the international and national scene.
Video supplement. The development of ARR/ASC is illustrated in the linked video, which shows scenes from 1962 and 2017 (https://doi.org/10.5446/38276, Abrahamsen, 2017). 


\section{Appendix A}

In the years from 1975 to 1990 many of the activities at ARR were centred on large international campaigns under the auspices of SCOSTEP and COSPAR. These campaigns targeted specific problem areas; they involved many scientific groups, several research ranges, and many sounding rockets and ground-based instruments. ARR played an important role in these research programmes. The results were interpreted and published jointly in special issues of the Journal of Atmospheric and Terrestrial Physics.

The campaigns were as follows:

- The Winter Anomaly Campaign (1975/76), J. Atmos. Terr. Phys., 41, 10-11, 1979. This programme studied the anomalous absorption of radio waves in the lower ionosphere observed in winter at middle and high latitudes. Rockets were launched from Huelva in Spain. The campaign contributed significantly to the understanding of this phenomenon. The principal investigator (PI) was Dirk Offermann, Gesamthochschule Wuppertal $(\mathrm{GW})$.

- The Energy Budget Campaign (1980), J. Atmos. Terr. Phys., 47, 1-2-3, 1985. This campaign focussed on energetic processes in the upper atmosphere. It was conducted from two ranges, ESRANGE and ARR, simultaneously, PI was Dirk Offermann, GW (at ESRANGE); deputy PI was Eivind V. Thrane, FFI (at ARR).
- Middle Atmosphere Physics Winter in Northern Europe (MAP/WINE 1983-1984), J. Atmos. Terr. Phys., 49, 7-8, 1987. MAP/WINE studied winter phenomena such as stratospheric warmings and their relations to the physics of the mesosphere and lower ionosphere. The ARR campaign lasted for several months. PI was Ulf von Zahn, Bonn University; deputy PI was Eivind V. Thrane, FFI.

- Middle Atmosphere Cooperation Summer in Northern Europe (MACSINE July-August 1987) and MAC Epsilon (October-November 1987), J. Atmos. Terr. Phys., 52, 10-11, 1990. ARR was the centre for both campaigns. MACSINE studied summer phenomena, while MACEpsilon focussed on the role of turbulence in the middle atmosphere. In the latter campaign five instrumented rockets were launched in one salvo (within 80 s). PI was Eivind V. Thrane, FFI; deputy PI was Ulf von Zahn, BU.

- Dynamics Adapted Network of the Atmosphere (DYANA 1990), J. Atmos. Terr. Phys., 56, 13-14, 1994. This campaign studied the dynamics of the upper atmosphere on a global scale. ARR was the centre, but coordinated rocket launches were made from ranges in Asia, Europe and North America. PI was Dirk Offermann, GW, with Eivind V. Thrane, FFI, as deputy. 
Competing interests. The author declares that he has no conflict of interest.

Special issue statement. This article is part of the special issue "History of geophysical institutes and observatories". It is not associated with a conference.

Acknowledgements. The author gratefully acknowledges the support of CEO and President Odd Roger Enoksen and his staff at ASC. An invitation to visit ASC during the preparation of the manuscript proved very useful, and many of the staff members provided information and advice. The author would also like to thank Tom Arild Blix (FFI) and Jøran Idar Moen (University of Oslo) for valuable assistance.

Edited by: Asgeir Brekke

Reviewed by: Martin Friedrich, Olav Holt, and one anonymous referee

\section{References}

4321 fire!: Part 1. Historien om Andøya Rakettskytefelt. Part 2. Scientific results from Andøya Rocket Range, Boksenteret Erik Pettersen \& Co AS, 2002.

Abrehemsen, T.: asc-then-and-now, Andoya Space Center, https://doi.org/10.5446/38276, 2017.

Bjordal, J., Trefall H., Ullaland, S., Beversdorff, A., Kangas, J., Tanskanen, P., Kremser, G., Saeger, K. H., and Specht, H.: On the morphology of Auroral Zone X-ray Events, J. Atmos. Terr. Phys., 33, 1289-1303, https://doi.org/10.1016/0021-9169(75)90122-1, 1971.

Collett, J. P. (Ed.): Making Sense of Space: The History of Norwegian Space Activities, Scandinavian University Press, Oslo, ISBN 82-00-22692-1, 1995.

Dynamics Adapted Network of the Atmosphere (DYANA 1990), Guest Editor: Offermann, D., J. Atmos. Terr. Phys., 56, 13-14, 1994.

The Energy Budget Campaign (1980), Guest Editor: Offermann, D., J. Atmos. Terr. Phys., 47, 1-2-3, 1985.
Feldstein, Y. I.: Auroral morphology I, Tellus, 16, 252-257, https://doi.org/10.1111/j.2153-3490.1964.tb00163.x, 1964.

Friedrich, M.: Handbook of the lower ionosphere, Verlag der Technischen Universität Graz, ISBN 978-3-85125-485-3, 2016.

Mæhlum, B. N., Måseide, K., Aarsnes, K., Egeland, A., Grandal, B., Holtet, J., Jacobsen, T. A., Maynard, N. C., Søraas, F., Stadsnes, J., Thrane, E. V., and Trøim, J.: Polar 5 - and electron accelerator experiment within an aurora. 1. Instrumentation and geophysical conditions, Planet. Space Sci., 28, 259-278, 1980.

Middle Atmosphere Cooperation Summer in Northern Europe (MACSINE July-August 1987) and MAC Epsilon (OctoberNovember 1987), Guest Editor: Thrane, E. V., J. Atmos. Terr. Phys., 52, 10-11, 1990.

Middle Atmosphere Physics/Winter in Northern Europe (MAP/WINE 1983-84), Guest Editor: von Zahn, U., J. Atmos. Terr. Phys., 49, 7-8, 1987.

Moen, J. I., Oksavik, K., Abe, T., Lester, M., Saito, Y., Bekkeng, T. A., and Jacobsen, K. S.: First in-situ measurements of HF radar echoing targets, Geophys. Res. Lett., 39, L07104, https://doi.org/10.1029/2012GL051407, 2012.

Mortensen, W., Tønnesen, T., Havnes, O., Olsen, S., Angeltveit, T., and Trøim, J.: Miniaturization of Sounding Rocket Payload Instrumentation for Use with very Small Single Stage Rockets, 13th ESA Symposium on European Rocket and Balloon Programmes and Related Research, 1997-05-26-1997-05-29, 1997.

Lübken, F.-J., Rapp, M., Blix, T., and Thrane, E.: Microphysical and turbulent measurements of the Schmidt number in the vicinity of polar mesosphere summer echoes, Geophys. Res. Lett., 25, 893 896, 1998.

Oksavik, K., Moen, J., Lester, M., Bekkeng, T. A., and Bekkeng, J. K.: In-situ measurements of plasma irregularity growth in the cusp ionosphere, J. Geophys. Res., 117, A11301, https://doi.org/10.1029/2012JA017835, 2012.

Pfaff, R. F., Borovsky, J. E., and Young, D. T. (Eds.): Measurement Techniques in Space Plasmas, Geophys. Monogr., Am. Geophys. Union, 103, https://doi.org/10.1029/GM103, 1998.

Thrane, E. V.: Ionosfæreforskning, fra Kjeller til Saturn, Historie Forsvarets Forskningsinstitutt, available at: http://www.ffi no/no/Publikasjoner/Documents/FFIs-historie-nr19.pdf (last access: 5 December 2018), 2003 (in Norwegian).

The Winter Anomaly Campaign (1975/76), J. Atmos. Terr. Phys., 41, 10-11, 1979. 